\title{
HAND-SEWN VERSUS STAPLER ESOPHAGOGASTRIC ANASTOMOSIS AFTER ESOPHAGEAL RESSECTION: SISTEMATIC REVIEW AND META-ANALYSIS
}

\author{
Anastomose esofagogástrica manual versus mecânica pós-ressecção esofágica: revisão sistemática e metanálise \\ Paula Marcela Vilela CASTRO, Felipe Piccarone Gonçalves RIBEIRO, \\ Amanda de Freitas ROCHA, Mônica MAZZURANA, Guines Antunes ALVAREZ
}

From the Centro Universitário Lusíada UNILUS and Departamento de Cirurgia Geral do Hospital Guilherme Álvaro (Lusiada University Center - UNILUS and Department of General Surgery of Guilherme Álvaro Hospital), Santos, SP, Brazil

\section{HEADINGS - Esophagectomy. Surgical} anastomosis. Meta-analysis.
ABSTRACT - Introduction: Postoperative anastomotic leak and stricture are dramatic events that cause increased morbidity and mortality, for this reason it's important to evaluate which is the best way to perform the anastomosis. Aim: To compare the techniques of manual (hand-sewn) and mechanic (stapler) esophagogastric anastomosis after resection of malignant neoplasm of esophagus, as the occurrence of anastomotic leak, anastomotic stricture, blood loss, cardiac and pulmonary complications, mortality and surgical time. Methods: A systematic review of randomized clinical trials, which included studies from four databases (Medline, Embase, Cochrane and Lilacs) using the combination of descriptors (anastomosis, surgical) and (esophagectomy) was performed. Results: Thirteen randomized trials were included, totaling 1778 patients, 889 in the hand-sewn group and 889 in the stapler group. The stapler reduced bleeding $(p<0.03)$ and operating time $(p<0.00001)$ when compared to hand-sewn after esophageal resection. However, stapler increased the risk of anastomotic stricture $(\mathrm{NNH}=33)$, pulmonary complications $(\mathrm{NNH}=12)$ and mortality $(\mathrm{NNH}=33)$. There was no significant difference in relation to anastomotic leak $(p=0.76)$ and cardiac complications $(p=0.96)$. Conclusion: After resection of esophageal cancer, the use of stapler shown to reduce blood loss and surgical time, but increased the incidence of anastomotic stricture, pulmonary complications and mortality.

\section{Correspondence:}

Paula Marcela Vilela Castro

pmarcela_13@hotmail.com

Financial source: none

Conflicts of interest: none

Received for publication: 23/10/2013

Accepted for publication: 22/04/2014

\author{
DESCRTORES - Esofagectomia. \\ Anastomose cirúrgica. Metanálise
}

RESUMO - Introdução: Deiscências e estenoses anastomóticas pós-operatórias são eventos dramáticos que causam aumento da morbimortalidade; por esta razão é sempre importante avaliar qual é o melhor meio de se fazer as anastomoses. Objetivo: Comparar as técnicas de anastomose esofagogástrica manual e mecânica, após ressecção de neoplasia maligna de esôfago, quanto à ocorrência de fístula, estenose, sangramento, complicações cardíacas e pulmonares, mortalidade e tempo cirúrgico. Métodos: Foi realizada uma revisão sistemática de ensaios clínicos randomizados, que incluiu estudos de quatro bases de dados (Medline Embase, Cochrane e Lilacs) usando a combinação dos descritores (anastomosis, surgical) and (esophagectomy). Resultados: Treze ensaios clínicos randomizados foram incluídos, totalizando 1778 pacientes, sendo 889 no grupo da anastomose manual e 889 no grupo da anastomose mecânica. A anastomose mecânica reduziu o sangramento $(p<0,03)$ e o tempo cirúrgico $(p<0,00001)$ quando comparado à anastomose manual pós ressecção esofágica. No entanto, a anastomose mecânica aumentou o risco de estenose ( $\mathrm{NNH}=33$ ), complicações pulmonares $(\mathrm{NNH}=12)$ e mortalidade $(\mathrm{NNH}=33)$. Não houve diferença significativa em relação à formação de fístulas $(p=0,76)$ e complicações cardíacas $(p=0,96)$. Conclusão: Após ressecção de neoplasia esofágica, o uso da anastomose mecânica demonstrou reduzir o sangramento e o tempo cirúrgico, porém aumentou a incidência de estenose, complicações pulmonares e mortalidade.

A ccording to the National Cancer Institute, in the period of 2006 to 2010, the incidence of esophageal cancer was 4,4/100.000 habitants per year, and at the same period the mortality rate was $4,3 / 100.000$ habitants per year. ${ }^{10}$ According to INCA, at the year of 2012, the new cases of esophageal cancer were estimated at 10.420 , being 7.700 in men and 2.650 in women. ${ }^{6}$ Therefore, it is a severe disease with poor prognosis.

The surgical resection is one option of treatment of esophageal cancer. The esophagogastric anastomosis is a basic component and aims to restore the continuity feed ${ }^{15}$, and can performed using manual (hand-sewn) or mechanical (stapled) suture.

The advent of stapled, released from the decade of 60 , by Ravitch \& Steichen ${ }^{21}$, caused the development of an apparatus characterized by increased security, accuracy and speed at this form trying to reduce the risk of anastomotic leak, beyond simplify the realization. ${ }^{11,19,24}$ The stapled decreases the occurrence of trauma, allows the uniformity of the anastomosis and a shorter surgical time; however, increases costs and the incidence of anastomotic stricture. The hand-sewn depends more of the surgeon ability and certainly is cheaper than stapled. ${ }^{15}$

Postoperative anastomotic leak and stricture are dramatic events that cause increased morbidity and mortality, for this reason it's important to evaluate which is the best way to perform the anastomosis. The anastomotic leak decreases the patient quality of life, retard early feedings, requires laborious local care and prolongs hospitalization. In addition, 
patients who develop anastomotic leak 30 to $50 \%$ progress to anastomotic stricture. Anastomotic stricture occurs in 5 to $46 \%$ of operated cases and can manifest up to a year after surgery. ${ }^{8}$

The purpose of this meta-analysis was to compare hand-sewn and stapled after resection of malignant neoplasm of esophagus.

\section{METHODS}

\section{Identification and selection of studies}

A search of electronic literature was done through the data bases Medline, Embase, Cochrane, and Lilacs. On Medline the combination of terms (anastomosis, surgical) and (esophagectomy) were utilized in the interface Clinical Queries (Therapy/Narrow[filter]). On Embase, was utilized the following search strategy: (anastomosis, surgical) and (esophagectomy) and (randomized controlled trial). On Lilacs and Cochrane, the keywords used were: (surgical anastomosis) and (esophagectomy). Manual searches were done among study references found. The searches ended on July 2, 2013.

The articles were selected independently and in pairs, by reading the titles and abstracts. Any difference between the articles was resolved by consensus.

\section{Inclusion and exclusion criteria}

Inclusion criteria: Randomized controlled trials were included irrespective of publication status, countries or languages; patients of any age and gender who underwent esophagectomy and reconstruction for esophageal cancer of any histological type; comparison of mechanic anastomosis and manual esophagogastric anastomosis. There were no restrictions on the path of reconstruction and the anastomotic site.

Exclusion criteria: Non-randomized trials, cohort, casecontrol and case report; patients undergoing emergency procedure and dealing only with benign esophageal diseases.

\section{Outcomes analyzed}

Primary outcomes: anastomotic leak and stricture.

Secondary outcomes: surgical time, bleeding, mortality, cardiac complications and pulmonary complications.

\section{Methodological quality}

The methodological quality of the primary studies was evaluated by the GRADE system proposed by the Grades of Recommendation, Assessment, Development and Evaluation group ${ }^{3}$.

\section{Statistical analysis}

The meta-analysis was performed with the Review Manager 5.2 program. Data were evaluated by intentionto-treat, meaning the patients that did not undergo the proposed intervention or patients lost in follow-up during the study were considered as clinical outcomes.

The evaluation of the dichotomic variables was performed by the difference in absolute risk (RD) adopting a $95 \%$ confidence interval. When there was a statistically significant difference between the groups, the number needed to treat (NNT) or the number needed to cause harm (NNH) was calculated. The continuous variables were evaluated by the difference in means (MD). Studies that did not show data in terms of means and their respective standard deviations were not included in the analyses.

\section{Heterogeneity and sensitivity analysis}

Inconsistencies among the clinical studies were estimated using the chi-squared heterogeneity test and quantified using $\mathrm{I}^{2}$. A value above $50 \%$ was considered substantial. Studies that generated heterogeneity were represented by funnel plots.
RESULTS

\section{Study Selection}

Through eletronic search 196 articles were recovered (Medline=42; Embase=89; Cochrane=34 e Lilacs=28). At manual search, three other articles were found beyond the previously selected. Initially 151 articles were excluded by not treating of randomized controlled trials. Thirty tree articles have been pre selected, but 20 did not meet the inclusion criteria. So at this revision, 13 randomized controlled trials were included (Figure 1).

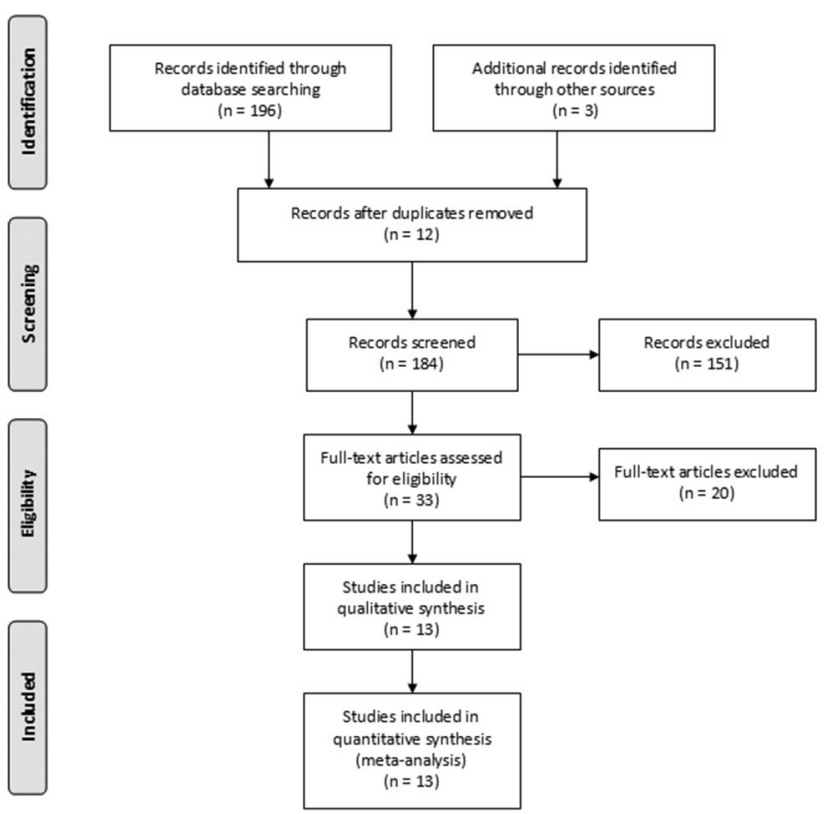

FIGURE 1 - Search algorithm of the articles. PRISMA adapted. $\mathrm{n}=$ number of articles

The 13 studies included randomized the patients in two groups, hand-sewn (group 1) and stapled (group 2), totaling 1778 patients, 889 from group 1 and 889 from group 2 .

Included studies, year of publication, number of patients in each group and histological type are shown on Table 1.

TABLE 1 - Description of the included studies

\begin{tabular}{|c|c|c|c|c|}
\hline Author & $\begin{array}{c}\text { Year of } \\
\text { Publication }\end{array}$ & $\begin{array}{c}\text { Number } \\
\text { of patients } \\
\text { manual } \\
\text { anastomosis }\end{array}$ & $\begin{array}{l}\text { Number } \\
\text { of patients } \\
\text { mechanic } \\
\text { anastomosis }\end{array}$ & $\begin{array}{c}\text { Histological } \\
\text { type of } \\
\text { neoplasm }\end{array}$ \\
\hline Wshasg ${ }^{27}$ & 1991 & 25 & 27 & NA \\
\hline Valverde ${ }^{25}$ & 1996 & 74 & 78 & NA \\
\hline Craig $^{5}$ & 1996 & 50 & 50 & $\mathrm{SCC}$ e $\mathrm{AC}$ \\
\hline $\operatorname{Law}^{15}$ & 1997 & 61 & 61 & SCC \\
\hline Laterza $^{14}$ & 1999 & 21 & 28 & $\mathrm{SCC}$ e $\mathrm{AC}$ \\
\hline Walther ${ }^{26}$ & 2003 & 41 & 42 & $\mathrm{SCC}$ e $\mathrm{AC}$ \\
\hline $\mathrm{Hsu}^{11}$ & 2004 & 32 & 31 & SCC \\
\hline Okuyama ${ }^{19}$ & 2007 & 18 & 14 & SCC \\
\hline Luechakiettisak $^{17}$ & 2008 & 59 & 58 & SCC \\
\hline Zhang $^{29}$ & 2010 & 244 & 272 & NA \\
\hline $\mathrm{Ma}^{18}$ & 2010 & 52 & 47 & $\mathrm{SCC}$ e AC \\
\hline Cayi ${ }^{4}$ & 2012 & 125 & 102 & $\mathrm{SCC}$ e $\mathrm{AC}$ \\
\hline Saluja ${ }^{22}$ & 2012 & 87 & 87 & $\mathrm{SCC}$ e $\mathrm{AC}$ \\
\hline
\end{tabular}

Legend: $\mathrm{SCC}=$ squamous cell carcinoma; $\mathrm{AC}=$ adenocarcinoma; $\mathrm{NA}=$ not available

Evaluation of methodological quality performed by GRADE is represented on Table 2. 
TABLE 2 - Methodological evaluation by GRADE

\begin{tabular}{|c|c|c|c|c|c|c|c|c|c|c|c|c|c|}
\hline Parameters Evaluated & 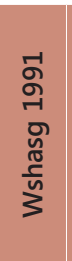 & $\begin{array}{l}\text { ুొ } \\
\text { ने } \\
\frac{0}{0} \\
\frac{0}{0} \\
\frac{2}{\pi}\end{array}$ & 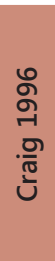 & $\begin{array}{l}\hat{S} \\
\text { ने } \\
3 \\
\text { త్ }\end{array}$ & 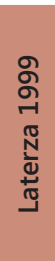 & 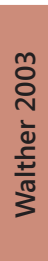 & 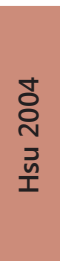 & 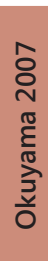 & 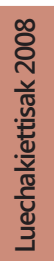 & $\begin{array}{l}0 \\
\text { ㄱ. } \\
\text { N } \\
\text { O } \\
\frac{c}{\pi} \\
\frac{N}{N}\end{array}$ & $\begin{array}{l}\text { 엉 } \\
\text { ᄋ } \\
\stackrel{\pi}{\Sigma}\end{array}$ & 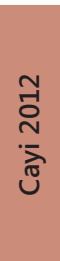 & 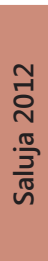 \\
\hline Was the study randomized? & $\mathrm{Y}$ & Y & Y & Y & Y & Y & Y & Y & Y & Y & Y & Y & Y \\
\hline Was the allocation of patients to groups confidential? & NA & Y & Y & NA & Y & Y & Y & $\mathrm{N}$ & Y & NA & Y & NA & Y \\
\hline $\begin{array}{l}\text { Were patients analyzed in the groups to which they were randomized } \\
\text { (was the analysis by intention to treat)? }\end{array}$ & $\mathrm{Y}$ & Y & Y & Y & Y & Y & Y & Y & Y & Y & Y & Y & $Y$ \\
\hline $\begin{array}{l}\text { Were patients in both groups similar with respect to the previously } \\
\text { known prognostic factors? }\end{array}$ & $Y$ & $Y$ & $Y$ & $Y$ & $Y$ & $Y$ & $Y$ & $Y$ & $Y$ & $Y$ & $Y$ & $Y$ & $Y$ \\
\hline Was the study blind? & $\mathrm{N}$ & $\mathrm{N}$ & $\mathrm{N}$ & $\mathrm{N}$ & $\mathrm{N}$ & $\mathrm{N}$ & $\mathrm{N}$ & $\mathrm{N}$ & $\mathrm{N}$ & $\mathrm{N}$ & $\mathrm{N}$ & $\mathrm{N}$ & $\mathrm{N}$ \\
\hline Except the experimental intervention, were the groups treated equally? & $\mathrm{Y}$ & Y & Y & Y & Y & $\mathrm{Y}$ & $\mathrm{Y}$ & Y & Y & Y & Y & Y & Y \\
\hline Were the losses significant? & NA & NA & $\mathrm{N}$ & $\mathrm{N}$ & $\mathrm{N}$ & $\mathrm{N}$ & $\mathrm{N}$ & $\mathrm{N}$ & $\mathrm{N}$ & $\mathrm{N}$ & $\mathrm{N}$ & $\mathrm{N}$ & $\mathrm{N}$ \\
\hline Did the study have a precision estimate for the effects of treatment? & Y & $\mathrm{Y}$ & Y & Y & Y & Y & $\mathrm{Y}$ & Y & $\mathrm{Y}$ & Y & Y & Y & Y \\
\hline Are the study patients similar to those of interest? & Y & Y & Y & Y & Y & Y & Y & Y & Y & Y & Y & Y & Y \\
\hline Are the outcomes of the study clinically relevant? & Y & Y & Y & Y & Y & Y & Y & Y & Y & Y & Y & Y & Y \\
\hline Were the potential conflicts of interest declared? & $\mathrm{N}$ & $\mathrm{N}$ & $\mathrm{N}$ & $\mathrm{N}$ & $\mathrm{N}$ & Y & $\mathrm{N}$ & $\mathrm{N}$ & $\mathrm{N}$ & Y & Y & $\mathrm{N}$ & Y \\
\hline
\end{tabular}

Legend: $\mathrm{Y}=\mathrm{yes}, \mathrm{N}=\mathrm{no}, \mathrm{NA}=$ not available

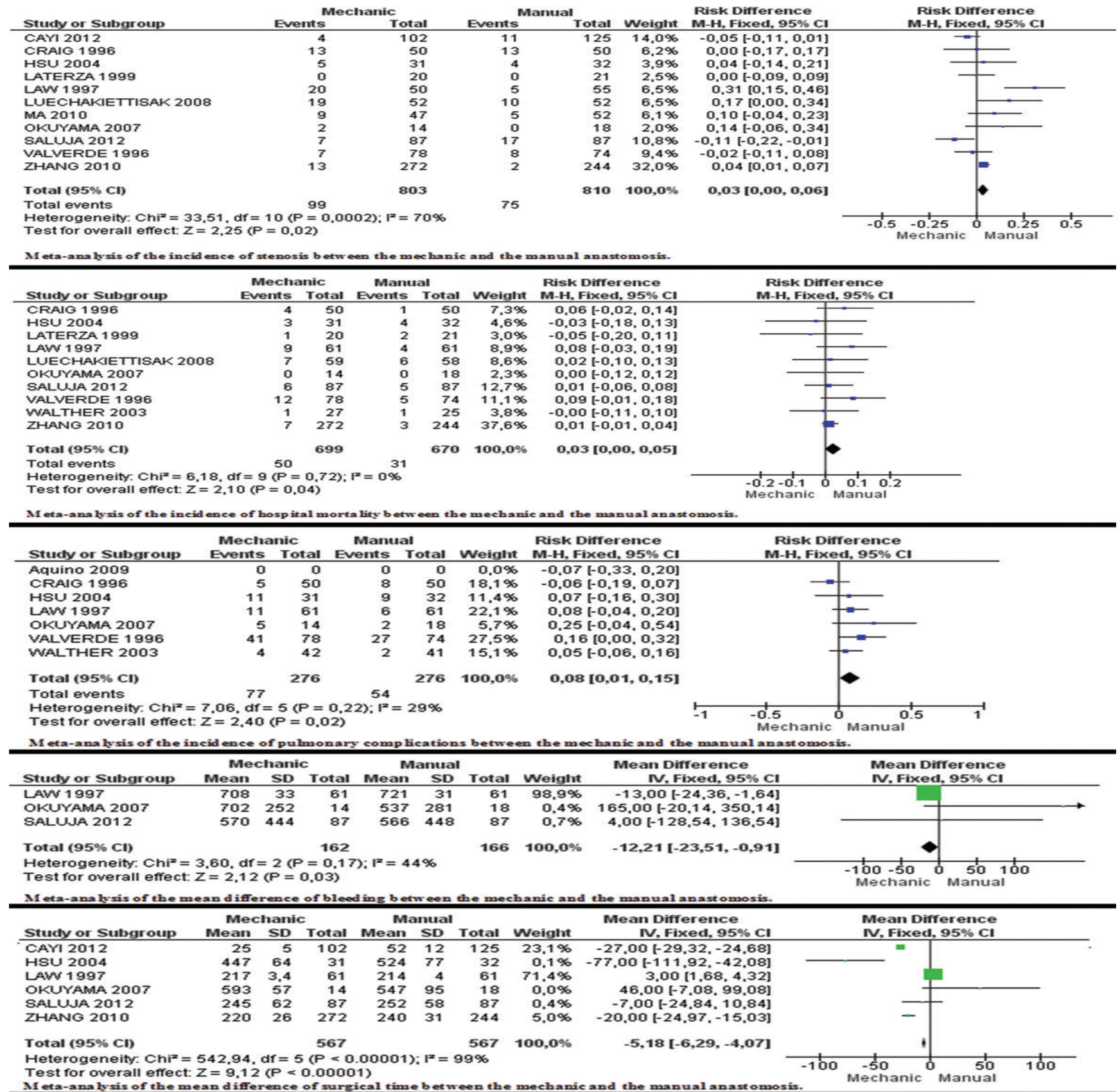

FIGURE 2 - Forest-plots of the analyzed outcomes 


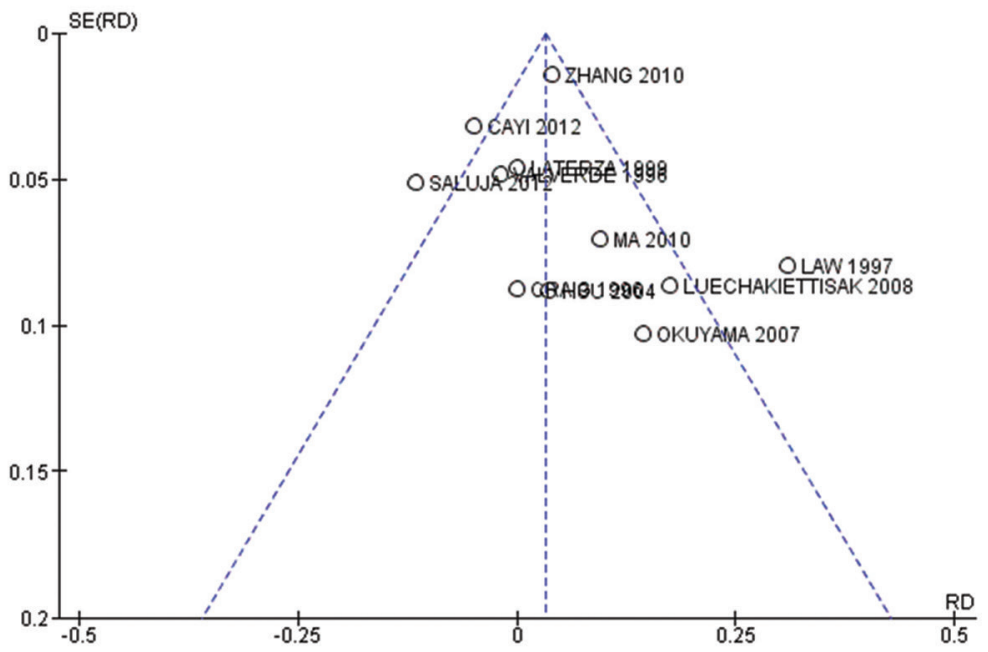

Funnel-p lot of the incidence of stenosis betw een the mechanic and the manual anastomosis.

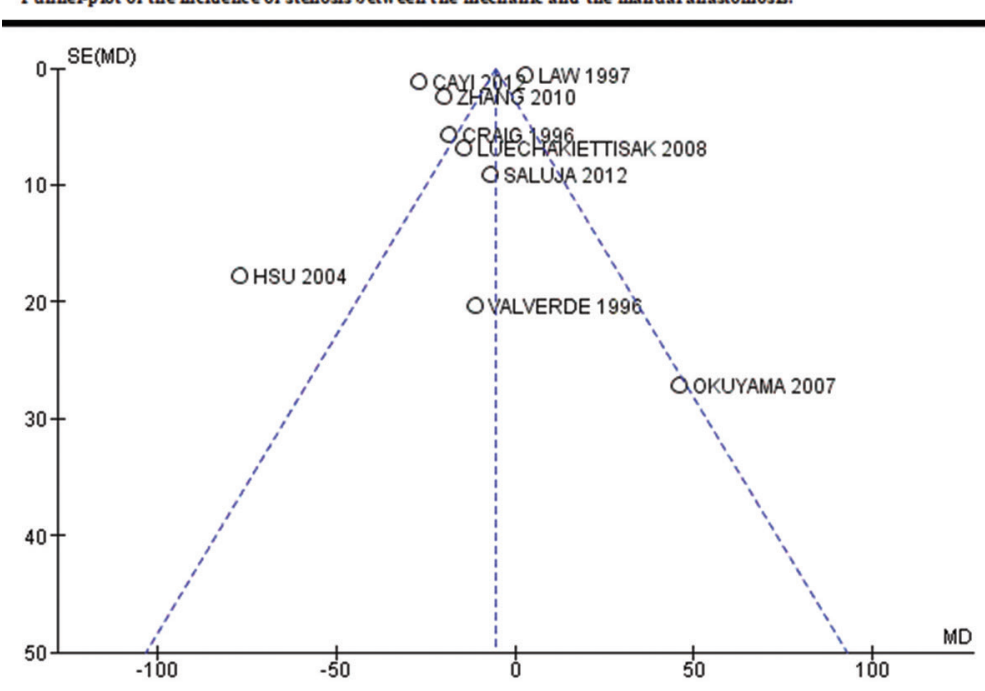

Funnel-p lot of the mean difference of sureical time between the mechanic and the manual anastomosis.

FIGURE 3 - Funnel-plots of the outcomes that presented heterogeneity above than 50\%

\section{Anastomotic stricture}

Eleven primary studies analyzed the anastomotic stricture outcome. The incidence of anastomotic stricture was $12,33 \%$ in stapled group (99 of 803 patients) and 9,26\% in hand-sewn group (75 of 810 patients). The mechanical anastomosis increased the absolute risk of anastomotic stricture in 3\% (CI 95\% 0,00 a 0,06; $p<0,0002$ e $\mathrm{I}^{2}=70 \%$ ), needing to treat 33 patients to obtain this harm (Figure 2).

\section{Anastomotic Leak}

Twelve primary studies analyzed the anstomotic leak outcome. The incidence of anastomotic leak was 7,13\% in the group of stapled (60 of 842 patients) and $7,77 \%$ in the group of hand-sewn (65 of 837 patients). There was no statistically significant difference between the two groups (RD -0.00; CI $95 \%-0,03$ a 0,$02 ; p=0.77$ e $\left.I^{2}=48 \%\right)$.

\section{Pulmonary complications}

Six primary studies analyzed the pulmonary complications outcome. The incidence of pulmonary complications was $27,90 \%$ in the stapled group (77 of 276 patients) and 19,56\% in the hand-sewn group (54 of 276 patients). The stapled increased the absolute risk of pulmonary complications in $8 \%$ (CI 95\% 0,01 a 0,14; $\mathrm{p}<0,02$ e I²=29\%), needing to treat 12 patients to obtain this harm (Figure 2).

\section{Cardiac complication}

Five primary studies analyzed the cardiac complication outcome. The incidence of cardiac complication was $17,94 \%$ in the stapled group (47 of 262 patients) and 18,22\% in handsewn group (47 of 258 patients). There was no statistically significant difference between the 2 groups (RD -0.00; CI 95\% $-0,07$ a 0,$06 ; p=0,96$ e $I^{2}=0 \%$ ).

\section{Blood Loss}

Three primary studies analyzed the blood loss outcome. The average difference between groups was 12,21 (CI 95\% 0,91 a 23,$51 ; p<0,03$ e $\left.I^{2}=44 \%\right)$. So, stapled generated less blood loss when compared with hand-sewn (Figure 2).

\section{Mortality}

This outcome considered in ten primary studies covers hospital mortality and 30 days mortality. The incidence was $7,15 \%$ in stapled group (50 of 699 patients) and 4,27\% in hand-sewn group (31 of 670 patients). The stapled increased the absolute risk of mortality in $3 \%$ (CI $95 \% \quad 0,00$ a 0,05 ; $\mathrm{p}<0,04$ e I$\left.^{2}=0 \%\right)$, needing to treat 33 patients to obtain this harm (Figure 2).

\section{Surgical time}

Six primary studies analyzed the surgical time outcome. The average difference between the groups was 5,18 (CI 95\% 4,07 a 6,29; $p<0,00001$ e $\left.I^{2}=99 \%\right)$. So the stapled dismissed less surgical time when compared with hand-sewn (Figure 2).

Each one of the funnel-plots of outcomes analyzed are represented in Figure 3. 
DISCUSSION

In 1960, at the Scientific Research Institute of Experimental Surgical Apparatus and Instruments in Moscow, a tubular instrument was devised to perform endto-end anastomosis in the gastointestinal tract, where they can be technically difficult, such as low rectal anastomosis, esophagogastric or esophagojejunal anastomosis. The instrument creates an inverting anastomosis held by a double staggered row of stainless steel wire staples creating an anastomosis $21.2 \mathrm{~mm}$ internal diameter with no significant inverted flange. ${ }^{21}$

Some authors have shown that prolonged surgery time due to extension esophageal resection can relate to Systemic Inflammatory Response Syndrome (SIRS), sepsis, intraoperative hemodynamic instability and this proved difficult to a proper healing of esophageal anastomosis. ${ }^{2,23}$

The majority of tumors classified as surgical are localized at middle and distal thoracic esophagus or at esophagogastric junction. In these cases the technique most used in the world is Ivor Lewis ${ }^{16}$ chest abdominal esophagogastrectomy followed by Orringer ${ }^{20}$ transhiatal esophagectomy (abdominal-cervical) and, less frequently by thoraco-abdomino-cervical technique. ${ }^{7}$

Systematic review and meta-analysis is a type of study of scientific accuracy for selecting the best avaible evidence in the medical literature, but should also assess the methodological quality of primary studies. This is necessary to obtaining accurate conclusions about the effect of interventions. To avoid distortions, it was decided to include only results with clinical and statistical homogeneity.

There are two systematic reviews in the literature about this topic: Urschel ${ }^{24}$ published in 2001 and Honda ${ }^{9}$ published in February 2013. The first includes five randomized controlled trials, counting with a total sample of 467 patients, being 231 in the hand-sewn group and 236 in the stapled group. This meta- analyses analized mortality, anastomotic leak, anastomotic sricture, cardiac and pulmonary morbidity. All the outcomes showed results statistically not significant. Already the second includes twelve randomized controlled trials, counting with a total sample of 1407 patients, being 692 in the hand-sewn group and 715 in the stapled group. This study evaluated anastomotic leak (not significant), anastomotic stricture (favorable to hand-sewn), surgical time (favorable to stapled), mortality after 30 days of surgery (not significant) and stapler diameter compared with anastomotic stricture.

In this review, the incidence of anastomotic stricture corresponds to $12,33 \%$ and $9,26 \%$ in groups of manual and mechanical anastomosis, respectively (CI95\% 0,00 a 0,06; $\mathrm{p}<0,0002$ ). Anastomotic leak occurred in $7,13 \%$ patients with mechanical anastomosis and $7,77 \%$ in manual (CI95\% $-0,03$ a 0,$02 ; p<0,77)$. Pulmonary complications were observed in $27,9 \%$ in mechanical anastomosis and in $19,56 \%$ in manual (CI95\% 0,01 a 0,14; $\mathrm{p}<0,02$ ). Regarding cardiac complications, $17,94 \%$ of patients with stapled and $18,22 \%$ with handsewn presented this outcome (CI95\% $-0,07$ a 0,06; $p<0,96)$. The mean difference of intraoperative blood loss was 12,21 (CI95\% -23,51 a $-0,91 ; \mathrm{p}<0,03)$, demonstrating that the stapled promoted less blood loss when compared with handsewn. In relation to surgical time, the stapled needed less time to be executed when compared with hand-sewn, with a mean difference of 5,18 (CI95\% -6,29 a -4,07; $p<0,00001)$.

Comparing the three studies (Urschel, Honda and this review), in relation to anastomotic leak, all meta-analyses showed statistically not significant results. In the outcome of anastomotic stricture, Urschel showed result statistically not significant, while the other two studies pointed favoring manual anastomosis. In cardiac complications both Urschel and this study showed no significant difference between both methods. Already in pulmonary complications, this study unlike Urschel showed difference between the procedures, once the stapled increases its absolute risk. About the outcome of operative time both Honda and these study pointed favoring stapled. On the outcomes of mortality both Urschel and Honda showed statistically not significant results. Already this study showed that the mechanical anastomosis increased the absolute risk of mortality compared to the manual.

One study $\left(\right.$ Aquino ${ }^{1}$ ) presented in Hondas review, was not included in this study due it did not comtemplate the inclusion criteria, once esophagectomy was for esophageal achalasia and not for neoplasm.

Urschel and Honda reviews used the Risk Ratio (RR) in the meta-analysis that should not be used in therapeutic studies, since they distort both the analysis of data as its heterogeneity. In this review, was chosen to express the results in the form of NNT and NNH when the data were statistically significant, which express respectively the required number of patients who need to be treated to obtain benefit or harm in the outcome analyzed.

In this review Jadad ${ }^{12}$ scale was not used for critical assessment of the methodological quality of primary studies, because it includes blinding parameter. It is know that in studies of surgical punch cannot perform the blinding of the surgeon. Thus, the maximum Jadad scale in this type of study would be 3, which would limit the selection of included studies. The Urschel study used the Jadad scale, but omits the scores assigned to the paper. As well as this paper Honda recognizes the impossibility to perform the complete blinding.

One possible source of bias may be the differences between the processes of randomization of the included studies. However, the quality of the allocation process was considered adequate in all studies. All the patients analyzed had defined eligibility criteria. In statistical analysis, the calculation of sample size and analysis by intention to treat were used. A common limitation of the analysis of surgical time and length of hospital stay was the lack of statistical measures such as standard deviation or present continuous data as median and range.

The study followed all the ethical and confidentiality principles of information that are recommended. For dealing with analysis of results already published in other articles, was not required formal approval from a research ethics committee.

\section{CONCLUSION}

After resection of esophageal cancer, the use of stapler shown to reduce blood loss and surgical time, but increased the incidence of anastomotic stricture, pulmonary complications and mortality.

\section{REFERENCES}

1. Aquino JL, Camargo JG, Said MM, Merhi VA, Maclellan KC, Palu BF. Avaliação da anastomose esofagogástrica cervical com sutura mecânica e manual em pacientes com megaesôfago avançado. Rev Col Bras Cir. 2008; 35(5).

2. Aquino JLB, Lopes LR Andreollo NA. Fistulas e deiscências na cirurgia do esôfago. In: Fraga G, Pereira GS, Lopes LR. Atualidades em Clinica Cirurgica. Intergastro e Trauma $20112^{a}$ ed. Rio de Janeiro: Editora Atheneu ; 2011. 325-333.

3. Brasil. Ministério da Saúde. Secretaria de Ciência, Tecnologia e Insumos Estratégicos. Departamento de Ciência e Tecnologia. Diretrizes metodológicas: elaboração de pareceres técnicocientíficos. Brasília; Ministério da Saúde; 2011. 79 p. tab (A. Normas e Manuais Técnicos). 
4. Cayi R, Li M, Xiong G, Cai K, Wang W. [Comparative analysis of mechanical and manual cervical esophagogastric anastomosis following esophagectomy for esophageal cancer]. Nan Fang Yi Ke Da Xue Xue Bao. 2012 Jun;32(6):908-9. Chinese.

5. Craig SR, Walker WS, Cameron EW, Wightman AJ. A prospective randomized study comparing stapled with handsewn oesophagogastric anastomoses. J R Coll Surg Edinb. 1996 Feb;41(1):17-9.

6. Disponível em: <www2.inca.gov.br/wps/wcm/connect/tiposdecancer/ site/home/esofago/definicao> Acesso em: 10 de julho de 2013

7. Gonzalez GL, Herrera MH, Padron JA, Justis EU. Anastomosis esofagogástrica látero-lateral con engrapadora lineal en la operación de Ivor Lewis. Rev Cub Med Mil. 2012 41(3): 292-301.

8. Henriques $A C$, Zanon $A B$, Godinho $C A$, Martins $L C$, Júnior $R$, Speranzini MB, Waisberg J. Estudo comparativo entre as anastomoses cervicais esofagogástricas término-terminal com e sem invaginação após esofagectomia para câncer. Rev Col Bras Cir. 2009; 36(5).

9. Honda M, Kuriyama A, Noma H, Nunobe S, Furukawa TA. Hand-sewn versus mechanical esophagogastric anastomosis after esophagectomy: a systematic review and metaanalysis. Ann Surg. 2013 Feb;257(2):238-48. doi: 10.1097/ SLA.0b013e31826d4723. Review.

10. Howlader N, Noone AM, Krapcho M, Garshell J, Neyman N, Altekruse SF, Kosary CL, Yu M, Ruhl J, Tatalovich Z, Cho H, Mariotto A, Lewis DR, Chen HS, Feuer EJ, Cronin KA (eds). SEER Cancer Statistics Review, 1975-2010, National Cancer Institute. Bethesda, MD, http://seer.cancer.gov/csr/1975_2010/

11. Hsu HH, Chen JS, Huang PM, Lee JM, Lee YC. Comparison of manual and mechanical cervical esophagogastric anastomosis after esophageal resection for squamous cell carcinoma: a prospective randomized controlled trial. Eur J Cardiothorac Surg. 2004 Jun;25(6):1097-101.

12. Jadad AR, Moore RA, Carroll D, Jenkinson C, Reynolds DJ, Gavaghan DJ, McQuay HJ. Assessing the quality of reports of randomized clinical trials: is blinding necessary? Control Clin Trials. 1996;17:1-12.

13. Kim RH, Takabe K. Methods of esophagogastric anastomoses following esophagectomy for cancer: A systematic review. J Surg Oncol. 2010 May 1;101(6):527-33. doi: 10.1002/jso.21510. Review.

14. Laterza E, de' Manzoni G, Veraldi GF, Guglielmi A, Tedesco $\mathrm{P}$, Cordiano C. Manual compared with mechanical cervical oesophagogastric anastomosis: a randomised trial. Eur J Surg. 1999 Nov;165(11):1051-4

15. Law S, Fok M, Chu KM, Wong J. Comparison of hand-sewn and stapled esophagogastric anastomosis after esophageal resection for cancer: a prospective randomized controlled trial. Ann Surg. 1997 Aug;226(2):169-73.

16. Lewis I. The surgical treatment of carcinoma of the oesophagus with special reference to a new operation for growths of the middle third. Br J Surg. 1946;34:18-31.
17. Luechakiettisak $P$, Kasetsunthorn S. Comparison of hand-sewn and stapled in esophagogastric anastomosis after esophageal cancer resection: a prospective randomized study. J Med Assoc Thai. 2008 May;91(5):681-5.

18. Ma RD, Zhang WT, Xu QR, Chen LQ. [Esophagogastrostomy by side-to-side anastomosis in prevention of anastomotic stricture: a randomized clinical trial]. Zhonghua Wai Ke Za Zhi. 2010 Apr 15;48(8):577-81. Chinese.

19. Okuyama M, Motoyama S, Suzuki H, Saito R, Maruyama K, Ogawa J. Hand-sewn cervical anastomosis versus stapled intrathoracic anastomosis after esophagectomy for middle or lower thoracic esophageal cancer: a prospective randomized controlled study. Surg Today. 2007;37(11):947-52. Epub 2007 Oct 25.

20. Orringer MB, Sloan H. Esophagectomy without thoracotomy. J Thorac Cardiovasc Surg. 1978;76:643.

21. Ravitch MM, Steichen FM. A stapling instrument for end-to-end inverting anastomoses in the gastrointestinal tract. Ann Surg. 1979 Jun;189(6):791-7.

22. Saluja SS, Ray S, Pal S, Sanyal S, Agrawal N, Dash NR, Sahni P, Chattopadhyay TK. Randomized trial comparing side-to-side stapled and hand-sewn esophagogastric anastomosis in neck. J Gastrointest Surg. 2012 Jul;16(7):1287-95. doi: 10.1007/s11605012-1885-7. Epub 2012 Apr 24.

23. Thornton FJ, Barbul AC. Cicatrização no trato gastrointestinal. Clin Cir Am Norte 1997; 3: 547-570

24. Urschel JD, Blewett CJ, Bennett WF, Miller JD, Young JE. Handsewn or stapled esophagogastric anastomoses after esophagectomy for cancer: meta-analysis of randomized controlled trials. Dis Esophagus. 2001;14(3-4):212-7.

25. Valverde A, Hay JM, Fingerhut A, Elhadad A. Manual versus mechanical esophagogastric anastomosis after resection for carcinoma: a controlled trial. French Associations for Surgical Research. Surgery. 1996 Sep;120(3):476-83.

26. Walther B, Johansson J, Johnsson F, Von Holstein CS, Zilling T. Cervical or thoracic anastomosis after esophageal resection and gastric tube reconstruction: a prospective randomized trial comparing sutured neck anastomosis with stapled intrathoracic anastomosis. Ann Surg. 2003 Dec; 238(6):803-12; discussion 812-4.

27. West of Scotland and Highland Anastomosis Study Group. Suturing or stapling in gastrointestinal surgery: a prospective randomized study. Br J Surg. 191 Mar;78(3):337-41.

28. Worrell S, Mumtaz S, Tsuboi K, Lee TH, Mittal SK. Anastomotic complications associated with stapled versus hand-sewn anastomosis. J Surg Res. 2010 Jun 1;161(1):9-12. doi: 10.1016/j. jss.2009.07.004. Epub 2009 Aug 6.

29. Zhang YS, Gao BR, Wang HJ, Su YF, Yang YZ, Zhang JH, Wang C. Comparison of anastomotic leakage and stricture formation following layered and stapler oesophagogastric anastomosis for cancer: a prospective randomized controlled trial. J Int Med Res. 2010 Jan-Feb;38(1):227-33. 